\title{
Corporate Social Responsibility (Csr) Dan Good Corporate Governance (Gcg) Sebagai Indikator Dalam Menilai Nilai Perusahaan
}

\author{
Vidi Hadyarti, Tubagus M. Mahsin
}

Fakultas Ekonomi dan Bisnis Universitas Trunojoyo Madura

\begin{abstract}
ABSTRAK
Berbagai macam pendekatan dalam pengukuran nilai perusahaan sudah banyak digunakan dalam berbagai penelitianpenelitian ilmiah. Hal ini menunjukkan berbagai pemikiran tentang nilai perusahaan, suatu nilai perusahaan yang menggambarkan kondisi suatu perusahaan selama beroperasi. Nilai perusahaan penting diketahui karena semakin tinggi nilai perusahaan menunjukkan kemakmuran para pemegang saham. Tulisan ini memcoba untuk menulis kembali pemaparan tentang Corporate Social Responsibility (CSR) dan Good Corporate Governance (GCG) sebagai salah satu indikator pengukuran nilai perusahaan. Suatu pendekatan yang bisa mempresentasikan makna yang lebih besar dari gambaran kondisi suatu perusahaan, sehingga sampai saat ini CSR dan GCG masih menjadi indikator bagi peneliti dalam pengukuran nilai perusahaan.

Kata Kunci : Corporate Social Responsibility, Good Corporate Governance, Tobin's Q
\end{abstract}

\section{PENDAHULUAN}

Pada saat ini terdapat berbagai macam indikator ekonomi yang digunakan untuk mengukur kinerja dalam bisnis. Penggunaan indikator sebagai alat ukur dari suatu variabel sangat diperlukan, hal ini terkait dengan memberikan sarana kemudahan dalam memahami maknanya. Tidak mudah memang untuk menentukan suatu indikator sebagai pengukur variabel, karena indikator tersebut harus mampu merepresentasikan variabel yang akan diukur secara tepat, sehingga secara ilmiah bisa diterima dan dipertanggungjawabkan kebenarannya sebagai 
indikator yang tepat untuk mengukur variabel.

Nilai perusahaan sangat penting karena dengan nilai perusahaan yang tnggi akan diikuti oleh tingginya kemakmuran pemegang saham. Semakin tinggi harga saham semakin tinggi pula nilai peruahaan. Nilai perusahaan yang tinggi menjadi keinginan para pemilik perusahaan, sebab dengan nilai yang tinggi menunjukkan kemakmuran pemegang saham juga tinggi. Kekayaan pemegang saham dan perusahaan dipresentasikan oleh harga pasar dari saham yang merupakan cerminan dari keputusan investasi, pendanaan, dan manajemen aset.

Indikator yang digunakan sebagai pengukur varable harus diuji terlebih dahulu untuk mengetahui ketepannya CSR sebagai salah satu indikator pengukuran variabel nilai perusahaan. CSR menjadi tren global, terutama munculnya produk-produk ramah lingkungan yang di produksi yang mementingkan kaidah sosial dan hak asasi manusia. Menurut Wirakusuma dan Yuniasih (2007), akuntabilitas dapat dipenuhi dan asimetri informasi dapat dikurangi jika perusahaan melaporkan dan mengungkapkan kegiatan CSRnya ke para stakeholders. Dengan pelaporan dan pengungkapan CSR, para stakeholders akan dapat mengevaluasi bagaimana pelaksanaan CSR dan memberikan penghargaan/sanksi terhadap perusahaan sesuai hasil evaluasinya.

Serta GCG sebagai indikator yang lain dalam pengukuran nilai perusahaan. Praktik dan pengungkapan CSR merupakan konsekuensi logis dari implementasi konsep GCG. Pada prinsipnya antara lain menyatakan bahwa perusahaan perlu memperhatikan kepentingan stakeholders - nya, sesuai dengan aturan yang ada dan menjalin kerja sama yang aktif dengan stakeholders demi kelangsungan hidup jangka panjang perusahaan. Mekanisme GCG di perusahaan dapat dijadikan sebagai infrastruktur pendukung terhadap praktik dan pengungkapan CSR di Indonesia, dengan adanya mekanisme GCG akan dapat mengurangi asimetri informasi. Konsep dari GCG dilatar belakangi oleh masalah pemisahan antara kepemilikan dengan pengelolaan di dalam perusahaan, yang selanjutnya dimodelkan dengan agency theory. Dalam mekanisme GCG, pemisahan antara kepemilikan dan pengendalian perusahaan merupakan upaya yang sangat penting untuk mewujudkan tata kelola perusahaan yang baik (Jensen dan Meckling, 1976). 


\section{TINJAUAN PUSTAKA}

\section{Teori Stakeholder}

Menurut Sugiharto (2007) Stakeholder theory mengatakan: "Bahwa perusahaan bukanlah entitas yang hanya beroperasi untuk kepentingannya sendiri namun harus memberikan manfaat bagi stakeholdernya (pemegang saham, kreditor, konsumen, supplier, pemerintah, masyarakat, analis dan pihak lain).” Dengan demikian, keberadaan suatu perusahaan sangat dipengaruhi oleh dukungan yang diberikan oleh stakeholder kepada perusahaan tersebut. Kelangsungan hidup perusahaan tergantung pada dukungan stakeholder dan dukungan tersebut harus dicari sehingga aktivitas perusahaan adalah untuk mencari dukungan tersebut.

\section{Teori Agensi (Principal-Agency Theory)}

Teori agensi merupakan konsep yang menjelaskan hubungan kontaktual antara principals dan agents. Pihak principals adalah pihak yang memberikan manfaat kepada pihak lain, yaitu agent, untuk melakukan semua kegiatan atas nama principals dalam kapasitasnya sebagai pengambil keputusan (Jensen dan Smith, 1984). Bisa dikatakan didalam hubungan keagenan tersebut terdapat suatu kontrak dimana satu orang atau lebih (agen) untuk melakukan jsuatu jasa atas nama principal dan member wewenang kepada agen untuk membuat keputusan yang terbaik bagi principal.

Prinsipal maupun agen merupakan pelaku utama dan keduanya mempunyai bargaining position masing-masing dalam menenpatkan posisi, peran dan kedudukannya.prinsipal sebagai pemilik modal memiliki akses pada informasi internal perusahaan sedangkan agen sebagai pelaku dalam praktek operasional perusahaan mempunyai informasi tentang operasi dan kinerja perusahaan secara riil dan menyeluruh. Posisi, fungsi, situasi, tujuan kepentingan dan latar belakang principal dan agen yang berbeda dan saling bertolak belakang tersebut akan menimbulkan pertentangan dan saling tarik menarik kepentingan (conflict of interest) dan pengaruh antara satu sama lain. Teori keagenan mengatakan sulit untuk mempercayai bahwa manajemen (agen) akan selalu bertindak berdasarkan kepentingan pemegang saham (prisipal), sehingga diperlukan monitoring dari 
pemegang saham (Copeland dan Weston, 1990).

\section{Corporate Social Responsibility (CSR)}

Corporate social responsibility (CSR) atau pertanggung-jawaban sosial perusahaan adalah mekanisme bagi suatu organisasi untuk secara sukarela mengintegrasikan perhatian terhadap lingkungan dan sosial ke dalam operasinya dan interaksinya dengan stakeholders, yang melebihi tanggung jawab organisasi di bidang hukum (Darwin, 2004 dalam Kusumadilaga, 2010).

Corporate social responsibility merupakan komitmen perusahaan atau dunia bisnis untuk kontribusi dalam pembangunan ekonomi yang berkelanjutan dengan menitikberatkan pada keseimbangan antara perhatian terhadap aspek ekonomi, sosial, dan lingkungan. Dengan adanya praktik corporate social responsibility maka diharapkan nilai perusahaan akan baik dimata masyarakat. Perusahaan besar dan memiliki biaya keagenan yang lebih besar tentu akan mengungkapkan informasi yang lebih luas hal ini dilakukan untuk mengurangi biaya keagenan yang dikeluarkan (Martina, 2012).

Pengungkapan Tanggung Jawab Sosial Perusahaan

Pengungkapan tanggung jawab sosial perusahaan yang sering juga disebut sebagai social disclosure, corporate social reporting, social accounting, merupakan cara mengkomunikasikan informasi sosial kepada stakeholders. Dengan adanya hal ini maka akan dapat diketahui apa saja aktivitas sosial yang dilakukan oleh perusahaan. Hal ini sangat penting mengingat dampak-dampak yang mungkin timbul akibat aktifitas perusahaan.

Global Reporting Initiative (GRI) adalah sebuah jaringan berbasis organisasi yang telah mempelopori perkembangan dunia, paling banyak menggunakan kerangka laporan keberlanjutan dan berkomitmen untuk terus-menerus melakukan perbaikan dan penerapan di seluruh dunia (www.globalreporting.org). Menggunakan pengukuran dengan indikator GRI dianggap yang paling tepat untuk pengungkapan CSR dalam penelitian ini.

Semakin berkembangnya isu tentang tanggung jawab sosial sebuah perusahaan, maka indikator-indikator GRI yang digunakan juga mengalami pembaharuan untuk mengukur pengungkapan CSR. Global Reporting Initiatives 
telah mengembangkan indeks GRI versi 4.0 (G4) yang bisa digunakan sebagai panduan pelaporan GRI yang terbaik bagi pelaporan yang efektif. Maka indeks GRI yang digunakan dalam penelitian ini menggunakan indeks GRI versi 4.0 (G4).

Global Reporting Initiatives dalam website resminya menjelaskan dibandingkan versi sebelumnya, versi G4 ini lebih menekankan penekanan yang lebih besar atas kebutuhan organisasi tentang fokus dalam proses pelaporan dan laporan final yang berisi topik-topik yang bersifat material bagi bisnis dan pemangku kepentingan. Fokus terhadap materialitas ini akan menghasilkan pengungkapan yang lebih relevan dan kredibel (www.globalreporting.org).

Corporate Social Responsibility yang diukur dengan Corporate Social Responsibility Indesks (CSRI) berdasarkan GRI versi 4 dengan melihat enam indikator kinerja yang terdiri dari 91 item. Indeks diperoleh dari analisa pasa laporan keuangan tahunan perusahaan. Enam indikator kinerja berdasarkan GRI versi 4 yaitu:

a. Ekonomi (AEC), yang terdiri dari 9 item

b. Lingkungan (AEN), yang terdiri dari 34 item

c. Tenaga Kerja (ALA), yang terdiri dari 16 item

d. Hak Asasi Manusia (AHR), yang terdiri dari 12 item

e. Sosial Masyarakat (ASO), yang terdiri dari 11 item

f. Tanggung Jawab Produk (APR), yang terdiri dari 9 item

Rumus perhitungan pengungkapan CSR adalah sebagai berikut:

$\Sigma$ Eij

$\mathrm{CSRIj}=$

nj

Dimana :

CSRIj = Corporate Social Responsibility Index perusahaan $\mathrm{j}$

$\mathrm{nj}=$ Jumlah item untuk perusahaan $\mathrm{j}$

$\mathrm{nj}=91$ ( Skor maksimal)

$\Sigma$ Eij $=$ Jumlah total pengungkapan $\mathrm{CSR}$ oleh perusahaan 
Penghitungan CSR dilakukan dengan menggunakan variabel dummy yaitu :

Score 0 :

Jika perusahaan tidak mengungkapkan item pada daftar pertanyaan.

Score 1:

Jika perusahaan mengungkapkan item pada daftar pertanyaan.

Indeks pengungkapan CSR berdasarkan standar GRI (Global Reporting Initiative), yaitu sebagai berikut :

a. Indikator Kinerja Ekonomi (economic performance indicator)

b. Indikator Kinerja Lingkungan (environment performance indicator)

c. Indikator Kinerja Tenaga Kerja (labor practices performance indicator)

d. Indikator Kinerja Hak Asasi Manusia (human rights performance indicator)

e. Indikator Kinerja Sosial (social performance indicator)

f. Indikator Kinerja Produk (product responsibility performance indicator)

\section{Good Corporate Governance (GCG)}

FCGI dalam publikasi yang pertamanya mempergunakan definisi Cadbury Committee, yaitu: seperangkat peraturan yang mengatur hubungan antara pemegang saham, pengurus (pengelola) perusahaan, pihak kreditur, pemerintah, karyawan serta para pemegang kepentingan intern dan ekstern lainnya yang berkaitan dengan hak-hak dan kewajiban mereka, atau dengan kata lain suatu sistem yang mengatur dan mengendalikan perusahaan.

Disamping itu FCGI juga menjelaskan, bahwa tujuan dari Corporate Governance adalah untuk menciptakan nilai tambah bagi semua pihak yang berkepentingan (stakeholders). Secara lebih rinci, terminologi Corporate Governance dapat dipergunakan untuk menjelaskan peranan dan perilaku dari Dewan Direksi, Dewan Komisaris, pengurus (pengelola) perusahaan, dan para pemegang saham.

Good Corporate Governance (GCG) merupakan suatu keharusan dalam rangka membangun kondisi perusahaan yang tangguh dan sustainable. Diharapkan 
dengan pengimplementasian GCG, maka pengelolaan sumberdaya perusahaan diharapkan menjadi efektf, efisien, ekonomis dan produktif dengan selalu berorientasi pada tujuan perusahaan dan memperhatikan stakeholders approach. (Hardianto, 2013).

\section{Prinsip Good corporate Governance}

Ada empat unsur penting dalam Corporate Covernance menurut OECD (Organization for Economic Co-operation and Development) yang dikutip oleh FCGI dalam terbitannya, yaitu:

1. Fairness (Keadilan). Menjamin perlindungan hak-hak para pemegang saham, termasuk hak-hak pemegang saham minoritas dan para pemegang saham asing, serta menjamin terlaksananya komitmen dengan para investor.

2. Transparency (Transparansi). Mewajibkan adanya suatu informasi yang terbuka, tepat waktu, serta jelas, dan dapat diperbandingkan yang menyangkut keadaan keuangan, pengelolaan perusahaan, dan kepemilikan perusahaan.

3. Accountability (Akuntabilitas). Menjelaskan peran dan tanggung jawab, serta mendukung usaha untuk menjamin penyeimbangan kepentingan manajemen dan pemegang saham, sebagaimana yang diawasi oleh Dewan Komisaris (dalam Two Tiers System).

4. Responsibility (Pertanggungjawaban). Memastikan dipatuhinya peraturan serta ketentuan yang berlaku sebagai cerminan dipatuhinya nilai-nilai sosial. (OECD Business Sector Advisory Group on Corporate Governance, 1998)

Prinsip-prinsip Corporate Governance dari OECD menyangkut hal-hal sebagai berikut:

1. Hak-hak para Pemegang Saham

2. Perlakuan yang sama terhadap para pemegang saham

3. Peranan semua pihak yang berkepentingan (stekeholders) dalam Corporate Governance

4. Transparansi dan Penjelasan;

5. Peranan Dewan Komisaris

Prinsip-prinsip GCG yang jelaskan diharapkan dapat memberikan manfaat dan tujuan yang diperoleh bagi suatu perusahaan. Menurut Forum of Corporate Governance in Indonesia (FCGI), manfaaat pelaksanaan GCG yang diperoleh 
antara lain:

1. Meningkatkan kinerja perusahaan melalui terciptanya proses pengambilan keputusan yang lebih bai, meningkatkan efisiensi operasional perusahaan serta lebih meningkatkan pelayanan kepada stakeholder,

2. mempermudah diperolehnya dana pembiayaan yang lebih murah dan tidak rigid (karena faktor kepercayaan) yang pada akhirnya akan meningkatkan Corporate Value,

3. Mengembalikan kepercayaan investor untuk menanamkan modalnya diperusahaan,

4. Pemegang saham akan puas dengan kinerja perusahaan karena sekaligus akan meningkatkan shareholder value dan deviden.

Sedangkan tujuan penerapan Good Corporate Governance suatu perusahaan antara lain:

1. Mengoptimalkan pemberdayaan sumber daya ekonomis dari sebuah usaha,

2. Melindungi kepentingan pemegang saham dan memperhatikan kepentingan stakeholder lainnya,

3. Meningkatkan iklim investasi nasional,

4. Memperbesar keuntungan secara nasional dari sebuah usaha yang dikelola secara baik. Pencapaian prestasi yang lebih baik dan penghematan sumber daya dan modal secara ekonomis akan menigkatkan produktivitas dalam negeri ketika bersaing dipasar internasional.

Banyaknya berbagai pendapat tentang definisi dan tujuan Corporate Governance, namun ada prinsip dasar yang berlaku universal. Jika suatu perusahaan ingin berhasil di pasar yang bersaing, perusahaan harus mempunyai pengelola perusahaan yang inovatif, yang bersedia untuk mengambil risiko yang wajar, dan yang senantiasa mengembangkan strategi baru untuk mengantisipasi situasi yang berubah-ubah.

\section{Corporate Governance Preception Index (CGPI)}

Corporate Governance Preception Index (CGPI) adalah program riset dan 
pemeringkatan penerapan GCG pada perusahaan-perusahaan di Indonesia melalui perancangan riset yang mendorong perusahaan meningkatkan kualitas penerapan konsep Corporate Governance (CG) melalui perbaikan yang berkesinambungan (Continuous Improvement) dengam melaksanakan evaluasi dan benchmarking.

Program riset dan pemeringkatan CGPI yang diselenggarakan oleh The indonesia Institude for Corporate Governance (IICG) bekerja sama dengan majalah SWA sebagai mitra media publikasi. Program ini dilaksanakan sejak tahun 2001 yang dilandasi pentingnya mengetahui sejauh mana perusahaanperusahaan tersebut telah menerpakn prinsip-prinsip GCG. Dalam pemeringkatan CGPI ini nantinya di setiap akhir tahun akan diberikan suatu bentuk apresiasi penghargaan terhadap inisiatif dari upaya perusahaan dalam mewujudkan bisnis yang sesuai dengan GCG melalui CGPI Awards dan penobatan sebagai perusahaan terpercaya yang hasil dari penghargaan ini akan di umumkan di majalah SWA sebagai sajian utama.

Hasil pemeringkatan program CGPI menggunakan norma penilaian berdasarkan rentang skor yang dicapai oleh peserta CGPI dengan kategorisasi atas tingkat kualitas implementasi GCG seperti dalam tabel 2.1 berikut ini:

Tabel 2.1

Pemeringkatan CGPI

Skor CGPI Level Tepercaya

$85,00-100 \quad$ Sangat Tepercaya

70,00 - 84,99 Terpercaya

55,00 - 69,99 Cukup Terpercaya

\section{Nilai Perusahaan}

Nilai perusahaan didefinisikan nilai pasar karena nilai perusahaan dapat memberikan kemakmuran para pemegang saham secara maksimum apabila harga saham perusahaan meningkat. Berbagai kebijakan yang diambil manajemen dalam upaya untuk meningkatkan nilai perusahaan melalui peningkatan kemakmuran pemilik dan pemegang saham yang tercermin pada harga saham. (Brigham \& Houston, 2006:19). 
Menurut Samuel (2000) dalam Kusumadilaga (2010) menjelaskan bahwa enterprise value (EV) atau dikenal juga sebagai firm value (nilai perusahaan) merupakan konsep penting bagi investor, karena merupakan indikator bagi pasar menilai perusahaan secara keseluruhan. Sedangkan menurut Wahyudi (2005) dalam Kusumadilaga (2010) menyebutkan bahwa nilai perusahaan merupakan harga yang bersedia dibayar oleh calon pembeli andai perusahaan tersebut dijual. Dalam penilaian perusahaan terkandung unsur proyeksi, asuransi, perkiraan, dan judgment. Ada beberapa konsep dasar penilaian yaitu : nilai ditentukan untuk suatu waktu atau periode tertentu, nilai harus ditentukan pada harga yang wajar; penilaian tidak dipengaruhi oleh kelompok pembeli tertentu.

Ada beberapa rasio untuk mengukur nilai pasar perusahaan, misalnya price earning ratio (PER), market-to-book ratio, Tobin's Q, dan price flow ratio, marketto- sales ratio (Sukamulja, 2004) Rasio Tobin's Q dianggap rasio yang memberikan informasi paling baik karena menjelaskan fenomena dalam kegiatan perusahaan seperti misalnya terjadi perbedaan cross sectional dalam pengambilan keputusan investasi dan diversifikasi, hubungan antara kepemilikan saham manajemen dengan nilai perusahaan, hubungan antara kinerja manajemen dengan keuntungan dalam akuisisi, dan kebijakan pendanaan, dividen, dan kompensasi.

Dalam penelitian ini rasio yang digunakan dalam menilai nlai perusahaan adalah menggunakan Tobin's Q. Rasio ini dikembangkan oleh Profesor James Tobin (1967). Secara sederhana, Tobin's q adalah pengukur kinerja dengan membandingkan dua penilaian dari asset yang sama, tobin's q merupakan rasio dari nilai pasar aseet perusahaan yang diukur oleh nilai pasar dari jumlah saham yang beredar dan hutang (enterprise value) terhadap replacement cost dari aktiva perusahaan. (Fiakas, 2005 dalam Hadianto, 2013).

Apabila perusahaan memiliki nilai lebih besar dari nilai sebelumnya, maka akan memiliki biaya untuk meningkat kembali, dan memungkinkan untuk mendapat laba. Berdasarkan pemikiran Tobin, bahwa intensif untuk membuat modal investasi baru adalah tinggi ketika saham memberkan keuntungan di masa depan dan dapat dijual dengan harga yang lebih tinggi dari biaya investasinya (Fiakas, 2005 dalam Hadianto, 2013).

Jika nilai Q lebih besar 1 maka perusahaan bisa meningkatkan nilai 
persediaan mereka dengan meningkatkan modal, dan jika kurang satu, pasar saham menghargai modal kurang dari biaya penggantiannya dan perusahaan tidak akan mengganti persediaan modalnya bila telah dipakai.

Secara umum Tobin's Q hampir sama dengan market to book ratio, namun dalam Sukamulja (2004), Tobin's Q memiliki karakteristik yang berbeda antara lain :

1. Replacement Cost vs Book value

Tobin's Q menggunakan (estimated) replacement cost sebagai denominator, sedangkan market to book to book ratio menggunakan book value of total equiy.

Penggunaan replacement cost membuat nilai yang digunakan untuk menentukan Tobin's Q memasukkan berbagai faktor, sehingga nilai yang digunakan mencerminkan nilai pasar dari aset yang sebenarnya di masa kini, salah satu faktor tersebut inflasi.

\section{Total Asset vs Total Equity}

Market to book value hanya menggunakan faktor ekuitas (saham biasa dan preferen) dalam pengukuran. Penggunaan faktor ekuitas ini menunjukkan bahwa market to book ratio hanya memperhatikan satu tipe investor saja, yaitu investor dalam bentuk saham, baik saham biasa maupun preferen. Tobins'Q memberikan wawasan lebih luas terhadap pengertian investor. Perusahaan sebagai entitas ekonomi, tidak hanya menggunakan ekuitas untuk mendanai kegiatan operasionalnya, namun juga sumber lain seperti hutang, baik jangka pendek maupun jangka panjang.

Nilai perusahaan sangat penting karena dengan nilai perusahaan yang tinggi akan diikuti oleh tingginya kemakmuran pemegang saham. Semakin tinggi harga saham semakin tinggi pula nilai peruahaan. Nilai perusahaan yang tinggi menjadi keinginan para pemilik perusahaan, sebab dengan nilai yang tinggi menunjukkan kemakmuran pemegang saham juga tinggi. Kekayaan pemegang saham dan perusahaan dipresentasikan oleh harga pasar dari saham yang merupakan cerminan dari keputusan investasi, pendanaan, dan manajemen aset. 
Menurut Andayani (2008) nilai perusahaan dapat diukur melalui Tobin's Q, dengan perhitungan menggunakan rumus :

$$
\text { MVE + Debt }
$$

Tobin's $\mathrm{Q}=$

TA

Keterangan :

Tobin's Q = Nilai Perusahaan

MVE = Nilai pasar ekuitas

Debt $\quad=$ Total utang perusahaan

TA $\quad=$ Total Aktiva

Market Value Equity (MVE) diperoleh dari hasil perkalian harga saham penutupan akhir tahun dengan jumlah saham yang beredar pada akhir tahun.

\section{KESIMPULAN}

Berbagai model analisis keuangan menunjukkan kompleksitas atau keberagaman kondisi keuangan perusahaan. Oleh karena itu, diperlukan suatu alat ukur untuk mengevaluasi kondisi tersebut dengan menilai kinerja yang dihasilkan dalam suatu periode tertentu. Alat ukur tersebut digunakan untuk menilai dan memprediksikan kondisi dan kecenderungan kinerja perusahaan berdasarkan data historis yang dilaporkan dalam laporan akuntansi perusahaan.

Salah satu model yang digunakan untuk menilai suatu niali perusahaan adalah CSR. Model ini digunakan sebagai pengungkapan tanggung jawab sosial perusahaan, hal ini yang membuktikan kepedulian serta tanggung jawab perusahaan terhadap masyarakat serta lingkungan sekitar .

Model lain yang juga sangat populer dikalangan peneliti dan akademisi adalah GCG (Good Corporate Governance). Model ini berkaitan dengan tatakelola perusahaan, GCG berkaitan dengan CSR dimana perusahaan yang mempunyai tatakelola perusahaan yang baik pasti akan melakukan pengungkapan 
tanggung jawab sosial perusahaanya. Pemeringkatan perusahaan yang menerapkan GCG perusahaan yang sering disebut CGPI (Good Corporate Prece[tion Index) akan dipublikasikan pada majalah SWA.

Dua model indikator penilaian nilai perusahaan tersebut sampai saat ini masih digunakan dan menjadi salah satu pilihan yang menarik dan banyak digunakan oleh para peneliti dan akademisi untuk menganalisis kondisi, sebuah perusahaan.

\section{DAFTAR PUSTAKA}

Adawiyah, Ira Robiah, 2013. Pengaruh Tipe Industri, Ukuran Perusahaan, Profitabilitas,Dan

Leverage Terhadap Pengungkapan Corporate Social Responsibility (Studi empiris Pada Perusahaan Go Public yang Terdaftar Di Jakarta Islamic Index Periode 2008- 2012). Jakarta: Universitas islam Negeri Syarif Hidayatullah.

Andayani, Wiryan. 2008. Tanggung jawab sosial perusahaan, GCG dan kekayaan intelektual dan sebuah strategi pengolahan eksternal untuk meningkatkan nilai perusahaan. Skripsi.

Fakultas Ekonomi Universitas Islam Indonesia. Yogyakarta.

Antonius, YosepAnalisis. 2012. Pengaruh CSR Terhadap Kinerja Keuangan Pada Perusahaan Pertambangan dan Perkebunan Yang Terdaftar di BEI Tahun $2006-\quad$ 2010. Tesis.Universitas Indonesia.

Ardimas, Wahyu dan Wardoyo. 2014. Pengaruh Kinerja Keuangan dan CSR Terhadap Nilai Perusahaan pada Bank Go Public Yang Terdaftar di BEI. jurnal. Fakultas Ekonomi Universitas Gunadarma, Jakarta. ISBN: 978602-70429-1-9

Brigham, Eugene F and Joel F.Houston, 2006. Dasar-Dasar Manajemen Keuangan, alih bahasa Ali Akbar Yulianto, Buku satu, Edisi sepuluh, PT. Salemba Empat, Jakarta 
Dahlia, D. dan Siregar. 2008. Pengaruh Corporate Social Responsibility Terhadap Nilai Perusahaan Dengan Profitabilitas Sebagai Variabel Moderating (Studi Empiris pada Perusahaan Manufaktur yang terdaftar di Bursa Efek Indonesia). Skripsi. Program S1 Fakultas Ekonomi Universitas Diponegoro. Semarang.

Elkington, John. 1998. Canibals With Forks: The Triple Bottom Line in 21st Century Business, Gabriola Island, BC: New Society Publisher.

FCGI. 2003. Seri Tata Kelola Perusahaan (Corporate Governance) Jilid II. Jakarta: FCGI.

Ghozali, Imam, 2006. Aplikasi Multivariate dengan Prograsm SPS, Semarang: Universitas Diponegoro: Semarang.

Hadianto, Muhammad Lutfi. 2013. A nalisis Pengaruh Kinerja Keuangan Terhadap Nilai Perusahaan Dengan Pengungkapan CSR dan GCG Sebagai Variabel Pemoderasi (Studi Empiris Pada Perusahaan Consumer Goods yang Terdaftar di Bursa Efek Indonesia 2008-2011). Skripsi. UNDIP.

Harahap, Sofyan Safri, 2008. Analisa Kritis atas Laporan Keuangan, PT. Raja Grafindo Persada, Jakarta.

https://muhariefeffendi.files.wordpress.com/2009/12/fcgi_booklet_ii.pdf

Husnan dan Pudjiastuti. 2002. Dasar- Dasar Manajemen Keuangan. UPP STIM YKPN. Yogyakarta.

Indrawan, Danu Candra. 2011. Pengaruh CSR Terhadap Kinerja Perusahaan. Fakutas Ekonomi Universitas Diponegoro 
Semarang. Skripsi.

Jensen, Michael C. dan Clifford $\quad$ W. Smith, Jr. 1984. The Theory of Corporate. Finance: A Historical Overview. New York: Mc

Graw Hill.

Kasmir, 2012, Analisis Laporan Keuangan, PT.Raja Grafindo Persada,

Jakarta Lestari, Maharani Ika dan Toto Sugiharto. 2007. Kinerja

Bank Devisa dan Bank Non Devisa Dan Faktor-Faktor Yang

Mempengaruhinya. Proceeding PESAT (Psikologi, Ekonomi,

Sastra, Arsitek \& Sipil).

Kusumadilaga, Rimba. 2010. Pengaruh Corporate Social Responsibility

Terhadap Nilai Perusahaan Dengan Profitabilitas Sebagai

Variabel Moderating (Studi Empiris pada Perusahaan

Manufaktur yang terdaftar di Bursa Efek Indonesia). Skripsi

Fakultas Ekonomi. Universitas Dipenogoro. Semarang

Kusumajaya, Dewa Kadek Oka. 2011. Pengrauh Struktur Modal dan

Pertumbuhan Perusahaan Terhadap Profitabilitas dan Nilai

Perusahaan Pada Perusahaan Manufaktur di BEI. Program Pasca Sarjana Universitas Udayana Denpasar.

Sawir, Agnes, 2009. Analisis Kinerja Keuangan dan Perencanaan

Keuangan Perusahaan, PT. Gramedia Pustaka Utama,

Jakarta.

Sayekti, Yosefa dan Ludovicus Sensi Wondabio. 2007. Pengaruh CSR

Disclosure Terhadap ERC. Simposium Nasional Akuntansi

X. Makassar.

Septia, Ade Winda. 2015. Pengaruh Profitabilitas, Keputusan 


\begin{tabular}{|c|c|c|c|c|c|c|}
\hline & Investasi, & Keputusan & Pendanaan, da & n Kebijakan & \multicolumn{2}{|c|}{ Deviden } \\
\hline & ap Nilai & Perusahaan & Pada Perusahaan & Manufaktur & Ayng & Terdaftar \\
\hline $\mathrm{di}$ & BEI. $\quad \mathrm{P}$ & Im Studi & Manajemen & Fakultas & & Ekonomi \\
\hline
\end{tabular}

Sugiyono, 2011. Metode Penelitian Kuantitatif Kualitatif dan R\&D. Bandung Alfabeta.

Sukamulja, Sukmawati. 2004, “Good Corporate Governance di Sektor Keuangan: Dampak Good Corporate Governance Terhadap Kinerja Keuangan”. Vol.8.No.1. Juni 2004. Hal 1-25.

Syamsudin, Lukma, 2001. Manajemen Keuangan Perusahaan, PT. Raja Grafindo Persada, Jakarta.

Tumirin. 2007. Analisis Penerapan Good Corporate Governance dan Nilai Perusahaan. Jurnal BETA (Bisnis, Ekonomi, dan Akuntansi).6.

Van Horne, James C. dan M. Jhon Wachowicz, 2005. Prinsip - prinsip Manajemen Keuangan, Diterjemahkan oleh Aria Farahmita, Amanugrani, dan Taufik Hendrawan, edisi kedua belas, PT. Salemba Empat, Buku Satu, Jakarta. Veronica, Thedora

\begin{tabular}{cccc} 
Martina. 2012. Pengaruh Kinerja & \multicolumn{2}{c}{ Keuangan, Good } & Corporate \\
Governance dan Corporate Social & Responsibility terhadap Nilai \\
Perusahaan. Tesis Fakultas & Ekonomi. Universitas & Gunadarma.
\end{tabular}
Depok.

Weston, J.F. dan Copeland T.E., 1992. Dasar $\quad-\quad$ Dasar Manajemen Keuangan, Erlangga. 
Wahyudi, Isa dan Busyari Azheri. 2001. Corporate Social Responsibility: Prinsip, Pengaturan dan Implementasi. Malang: Setara Pers (Group Penerbit Intrans).

www.csrindonesia.com).

Yuniasih, Ni Wayan dan Wirakusuma, Made Gede, 2007, "Pengaruh Kinerja Keuangan Terhadap Nilai Perusahaan Dengan Pengungkapan Corporate Social Responsibility Dan Good Corporate Governance Sebagai Variabel Pemoderasi”, Universitas Udayana 